\title{
Platyspondyly and shortness of vertebral column in farmed Atlantic salmon Salmo salar in Norway-description and interpretation of pathologic changes
}

\author{
A. Kvellestad ${ }^{1, *}$, S. Høie ${ }^{1}$, K. Thorud ${ }^{1}$, B. Tørud ${ }^{2}$, A. Lyngøy ${ }^{3}$ \\ ${ }^{1}$ National Veterinary Institute, Box 8156 Dep., 0033 Oslo, Norway \\ ${ }^{2}$ Veterinary Service in Aquaculture, 6683 Vågland, Norway \\ ${ }^{3}$ Veterinary Service in Aquaculture, Dragsund, 6080 Gurskøy, Norway
}

\begin{abstract}
Body malformation due to shortness of the vertebral column, in most cases of unknown cause, has been observed in fish for more than $100 \mathrm{yr}$. It periodically occurs with high prevalence in farmed Atlantic salmon Salmo salar in Norway, and this paper describes the results of macroscopic, radiographic and histologic examination of parr and seawater-transferred fish. The vertebral bodies in both age groups did not acquire the length that they normally should due to a growth disturbance leading to the condition of platyspondyly and shortness in the column. The pathologic changes became visible at different ages in both groups and the process apparently starts in intervertebral tissues. There was proliferation of connective tissue and blood vessels, and sometimes infiltration with inflammatory cells, around affected vertebrae, especially in seawater-transferred fish. This is the first description of inflammation in abnormally short-spined fish, and it may indicate an infectious etiology, at least in farmed seawater-transferred salmon.
\end{abstract}

KEY WORDS: Norway $\cdot$ Aquaculture Atlantic salmon - Vertebral column - Disease Platyspondyly Sectional shortness

\section{INTRODUCTION}

Pathologic changes in the vertebral column of wild and farmed fish frequently involve either curvatures or shortness (Howes 1894, Gemmill 1912, Wunder 1949, Hübner 1961, Desse 1971). Shortness obviously comprises more than 1 pathologic condition (Howes 1894, Desse 1971, Komada 1983), but the descriptions, interpretations and naming of the lesions vary greatly in the several reports. However, a condition with a mainly straight column where some or all of the centra are too short, i.e. platyspondyly (Wunder 1971), and in some cases ankylosed, has been described in shark (Hoenig \& Walsh 1983) and wild and farmed teleost fish (Gemmill 1912, Schäferna 1923, Chabanaud 1939, Gill \& Fisk 1966, Rubens-Duval \& Desse 1972, Wunder 1975a,

•E-mail: agnar.kvellestad@vetinst.no
Henschke et al. 1982, Wells \& Cowan 1982, Hansen \& Yalew 1988). Genetic factors (Schäferna 1923, Wunder 1949, Hansen \& Yalew 1988) and exposure to toxicants (Wunder 1975a, Henschke et al. 1982, Wells \& Cowan 1982) have been proposed as causes of platyspondyly, but in most cases the etiology remains unknown.

Shortness of the vertebral column of unknown cause in Atlantic salmon has occurred with high prevalence in some seawater farms in Norway (McKay \& Gjerde 1986, Bæverfjord et al. 1996, Høie \& Breck 1996, Vågsholm \& Djupvik 1998). Fish with extensive changes are poor swimmers that are less efficient in competing for food, and seem to have lower tolerances to stress (Tørud pers. comm.). The condition also raises the issues of animal welfare and product quality.

A histology-based definition and understanding of diseases resulting in a short column are desirable before further work is done on the etiology. 
The purpose of this investigation is to describe and interpret pathomorphologic changes in the vertebral column of farmed freshwater and seawater Atlantic salmon with an abnormally short body length. A brief summary of the anatomy of the normal vertebral column is given, with special reference to structures in which pathologic changes occur. Emphasis is placed on the histologic examination of slight changes that we interpret as initial.

\section{MATERIALS AND METHODS}

One-year-old Atlantic salmon parr with and without external signs of a short column were sampled at vaccination. In addition, fish with various degrees of short and malformed bodies were sampled at 2 seawater farms. The fish were sent on ice to the laboratory (see Table 1 'Results'). Pathologic changes were graded as slight, moderate or extensive with respect to quality, and as few, some or many with respect to numbers. Fork length and weight were recorded, and condition factor (cf) calculated according to Fulton's formula ( $\mathrm{cf}=$ [weight in $\mathrm{g} \times 100] /[$ length in $\mathrm{cm}]^{3}$ ). Fish were radiographed laterally, and the percentage of columnal length with changes was calculated.

Body muscle along the left-hand side was removed, and the column was cleaved through the vertebral canal in a slightly paramedian plane. The right-hand sides of the columns were fixed in either $10 \%$ phosphate-buffered formalin or in Bouin's fluid. Short columnal sections with various degrees of change were processed further. Most of the formalin-fixed tissue was decalcified for 8 to $10 \mathrm{~h}$ in acid (Medite New Decalc, Medite GmbH, Burgdorf, Germany), and subsequently reimmersed in formalin. All tissues were then dehydrated through graded ethanols, cleared in xylene and embedded in paraffin. Sections were cut, from some blocks serially, in a median or paramedian plane. In addition, sections of intervertebral space and spinal cord with meninges were obtained in different planes from formalin-fixed, non-decalcified tissue. Sections were stained with Mayer's haemalum and eosin (HE) according to a procedure modified from Culling et al. (1985). Selected sections were stained with the van Gieson method, which stains the collagen red (Culling et al. 1985).

Additionally, whole vertebrae of 5 seawater-transferred fish were examined macroscopically and with stereomicroscopy after the soft tissues had been removed by boiling.

The findings in apparently normal columns, and most of the terminology used, are in accordance with previous descriptions of teleosts (Ebner 1896, Tret- jakoff \& Chinkus 1927, Remane 1936, Hübner 1961, François 1966).

\section{RESULTS}

Apart from changes in the vertebral column, no other macroscopic signs of disease were detected.

\section{Parr with no external signs of a short column}

Some anatomic terms are highlighted to give a background for the description of pathologic changes. The vertebral column comprises chordal tissue and perichordal vertebrae that are interconnected by ligaments (Figs. 1, 2 \& see 6 ). The centrum consists of compact bone forming a biconid tube, and of surrounding cartilage and cancellous bone. The biconid tube looks like an hourglass-shaped cylinder that can be divided into 2 concave halves - a cranial and a caudal end plate, for which we introduce the term component end plates. The term opposing end plates is introduced for the 2 end plates that belong to each of 2 adjacent biconid tubes and that limit the intercentral joint. Axial and abaxial (peripheral) directions refer to the columnal axis, which runs through the middle of the chorda and centra in the longitudinal direction. The end plates can be divided into dorsal, ventral and lateral sectors, all with the apex at the axis. The external intervertebral ligament, the internal periosteal ligament, and the more axial chordal tissue will be referred to as intercentral tissue. Intervertebral tissue comprises intercentral tissue and more abaxially located tissues between the vertebrae.
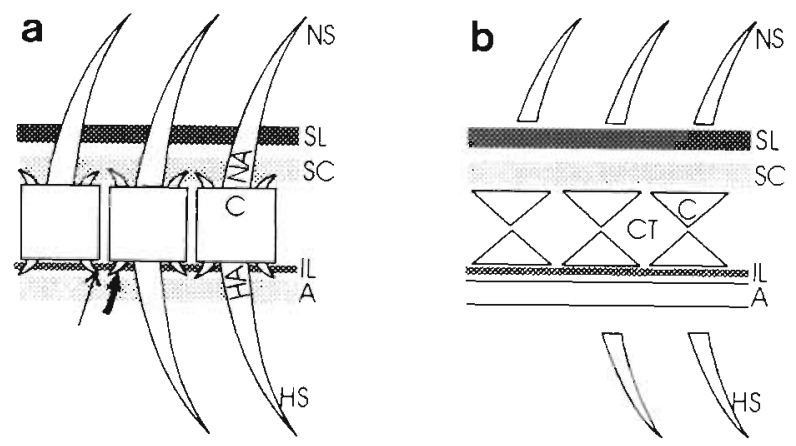

Fig. 1. Salmo salar. Centrum (C), neural arch (NA) and neural spine (NS), supraspinal ligament (SL), spinal cord (SC), haemal arch (HA) and haemal spine (HS), infraspinal ligament (IL), aorta (A), prezygapophysis (thick arrow) and postzygapophysis (thin arrow). (a) The zygapophyses exist as pairs (with 1) on each side of the median plane. (b) Median plane. Abbreviations as above plus: chordal tissue (CT) 
a

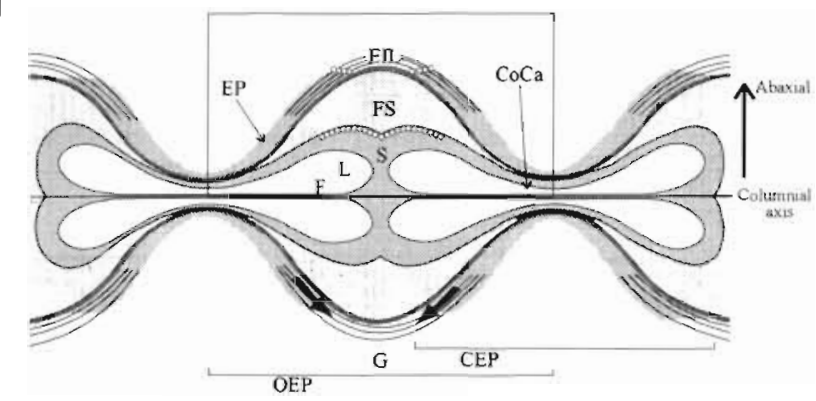

b

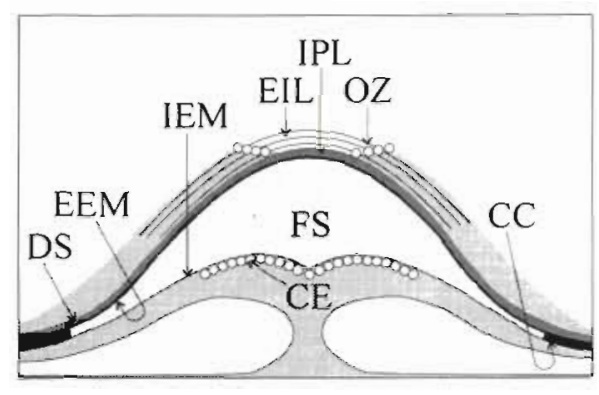

Fig. 2. Salmo salar. (a) Drawing of a randomly oriented plane along the columnal axis. (b) Structures within the rectangle are enlarged and details shown. Elements of perichordal tissue: end plate (EP), external intervertebral ligament (EIL), dense sheath (DS) and internal periosteal ligament (IPL). Each end plate has an osteogenic zone (OZ), and the thick arrows (a) show the direction of appositional growth. Cancellous bone, cartilage and other abaxial structures are not shown. Component end plates (CEP), opposing end plates (OEP) and gap (G) between centra. Elements of chordal tissue: external elastic membrane (EEN1), fibrous sheath (FS) with vestige of chordacentrum (CC), internal elastic membrane (IEM), chordal epithelium (CE), septum (S), fascicle (F) and lacuna (L) with its communicating canal (CoCa)

\section{Parr with external signs of a short column}

These 20 fish were shorter, of lower weight and of higher condition factor than the above-mentioned group (Table 1). The body and column were straight, and there was slight to extensive shortness of a body region in which the musculature bulged in dorsal and lateral directions (Fig. 3). Radiographic changes

Table 1. Salmo salar. Length, weight, condition factor, and radiographic, histologic and stereomicroscopic examination. N: number of fish examined; mean; min: minimal value recorded; max: maximal value recorded. F: formalin fixation; $D$ : decalcification; B: fixation in Bouin's fluid

\begin{tabular}{|c|c|c|c|c|c|c|}
\hline & \multicolumn{4}{|c|}{ Parr } & \multirow{2}{*}{\multicolumn{2}{|c|}{$\begin{array}{l}\text { Fish from seawater } \\
\text { External signs of } \\
\text { a short column }\end{array}$}} \\
\hline & \multicolumn{2}{|c|}{$\begin{array}{l}\text { No external signs } \\
\text { of a short column }\end{array}$} & \multicolumn{2}{|c|}{$\begin{array}{l}\text { External signs of } \\
\text { a short column }\end{array}$} & & \\
\hline & $\mathrm{N}$ & Mean $(\min -\max )$ & $N$ & Mean (min-max) & $N$ & Mean $(\min -\max )$ \\
\hline Length (cri) & 30 & $13.6(11.6-15.5)$ & 20 & $11.5(8.4-13.3)$ & & $58.8(33.0-74.0)$ \\
\hline Weight (g) & 30 & $31.9(20-46)$ & 20 & $26.9(19-36)$ & 19 & $2974(698-4828)$ \\
\hline Condition factor & 30 & $1.3(1.1-1.5)$ & 20 & $1.8(1.5-3.9)$ & 19 & $1.5(1.2-1.9)$ \\
\hline \multicolumn{7}{|l|}{ Radiographic examination } \\
\hline \multicolumn{6}{|l|}{ Percentage of columnal length } & $37(10-100)$ \\
\hline \multicolumn{7}{|l|}{ Histologic examination } \\
\hline \multirow{2}{*}{$\begin{array}{l}\text { Fish examined and method of tissue processing } \\
\text { Columnal segments (i.e. number of } \\
\text { paraffine blocks) examined }\end{array}$} & \multicolumn{2}{|c|}{$12 F, D$} & \multicolumn{2}{|l|}{$20 \mathrm{~F}, \mathrm{D}$} & \\
\hline & 12 & & 20 & & \multicolumn{2}{|c|}{$\begin{array}{c}1 F+2 B) \\
51\end{array}$} \\
\hline \multicolumn{5}{|l|}{ Stereomicroscopic examination } & \multicolumn{2}{|l|}{5} \\
\hline \multicolumn{7}{|l|}{${ }^{a}$ Two fish exhibited slight radiographic changes } \\
\hline
\end{tabular}

Fig. 3. Salmo salar. Radiograph of parr with changes in centra of 1 longer section and additionally in more caudally disseminated centra (arrow). $\times 1$

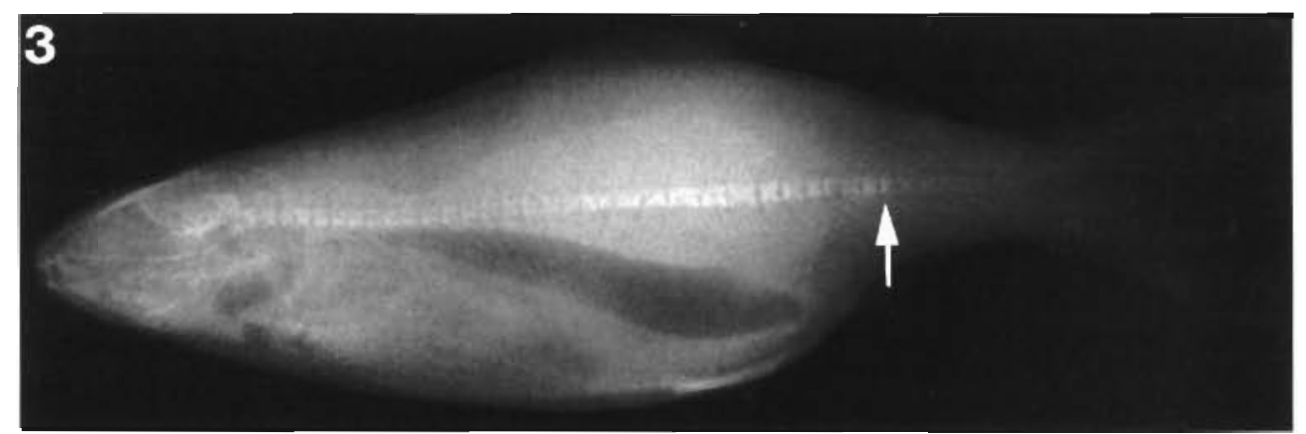

Note: In Figs. 3 to 26 in all photographs including parts of more than 1 centrum, left is cranial and up is dorsal 


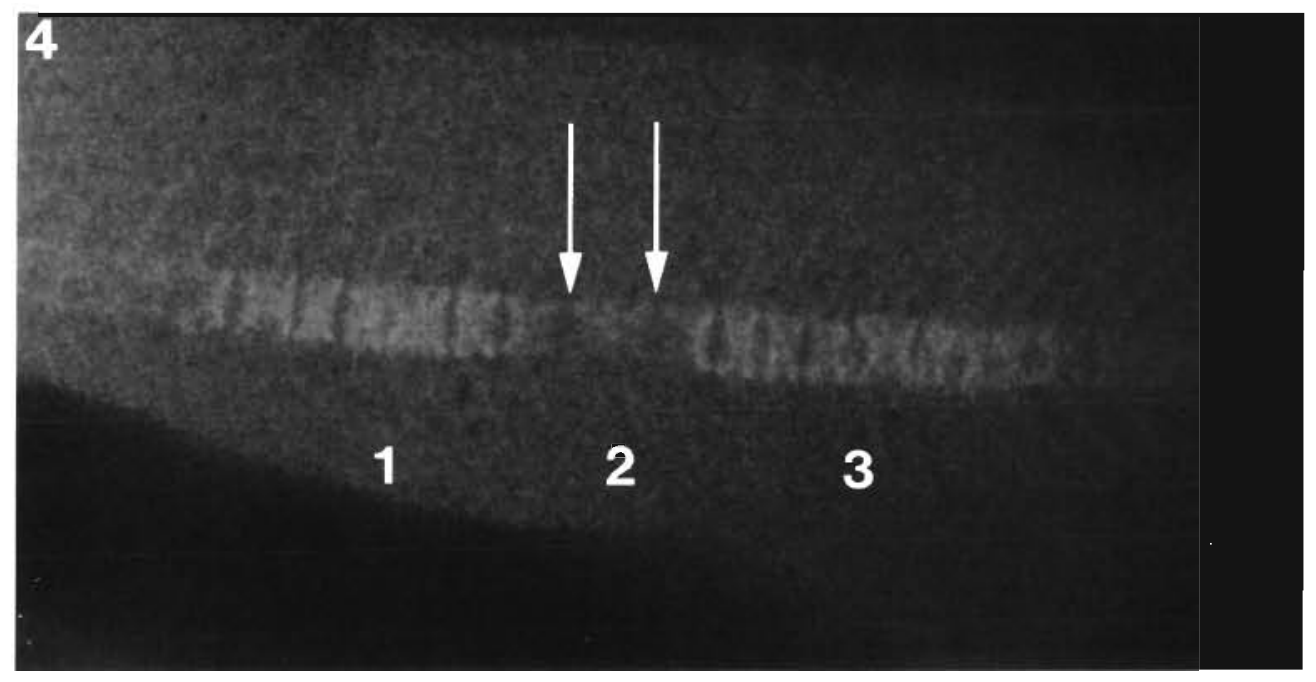

Fig. 4. Salmo salar. Radiograph of parr with changes located at 2 longer sections $(1$ and 3$)$ and at 1 consisting of 2 vertebrae (2). Between each section is only one intercentral space (long arrows) with no detectable change in opposing end plates. See also Figs. $9 \& 10$ of histologic section through the same centra. $\times 4$

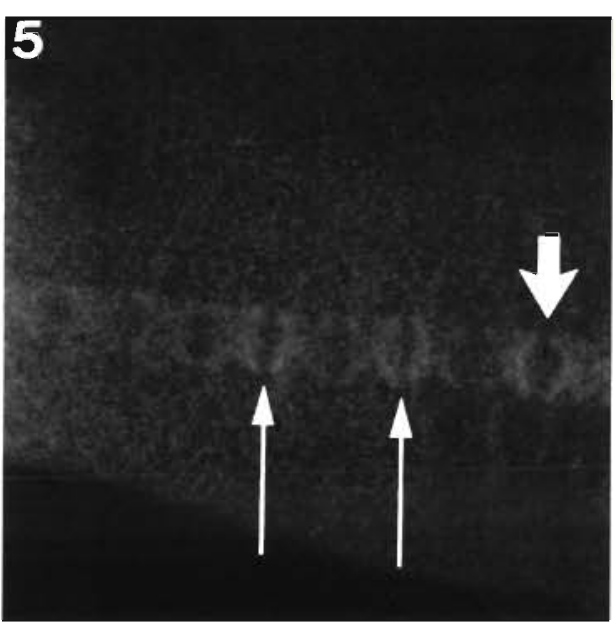

Fig. 5. Salmo salar. Increased radiodensity in opposing end plates only of 2 pairs of adjacent centra (thin arrows), and in transition to a section with changes (thick arrow). $\times 4$ on average affected $29 \%$ of columnal length (Table 1), and occurred mainly in these short body regions. Changes in 15 out of these 20 fish were located at the level of the dorsal fin and in the caudal half, and 2 fish possessed closely situated columnal sections with changes (Fig. 4).

In affected columnal sections, each centrum was short, of slightly increased diameter, showed increased radiodensity and was more difficult to sever with a scalpel. The neural spines of the most cranial vertebrae pointed in a cranio-dorsal direction. In 2 fish a few pairs of adjacent centra were seen with increased radiodensity in the opposing end plates only (Fig. 5).

Histologic changes along the column usually varied from slight to extensive in one and the same individual. The peripheries of the end plates in centra with slight to moderate changes were thickened and displayed a reduced degree of or no concavity, while the axial parts displayed the expected thickness and a high

Figs. 6 to 10. Salmo salar. Micrographs of median or paramedian sections. Formalin-fixed, decalcified. Figs. 6 to 8 . Abaxial part of intercentral space and opposing end plates (EP). Osteogenic zones (OZ), direction of appositional growth (long thin arrows), cellular external intervertebral ligament (ElL), acellular eosinophilic internal periosteal ligament (IPL, open curved arrow), external elastic membrane (arrowhead), fibrous sheath (FS), chordal epithelium (CE) and vacuolated chordal tissue (VCT). Fig. 6. No detectable changes. Internal elastic membrane (block arrow). $\mathrm{HE}, \times 300$. Fig. 7 . Moderate changes of end plates, with abaxial direction of growth from the borders of declining concavity (short arrows) and proliferation of cartilage-like tissue ( $\star$ ). IPL and more axial structures are irregular. HE,$\times 120$. Fig. 8 . Slight changes of end plates and vacuolated chordal epithelial cells (block arrow). $\mathrm{HE}, \times 120$. Fig. 9. Columnal sections shown in Fig. 4. Spinal cord (SC). Centrum $A$ is the most caudal one in Section 1, Centra B and $C$ belong to Section 2, and Centra $D$ and $E$ are the 2 most cranial ones in Section 3 . Ankylosis between Centra $B$ and $C_{1}$ in which the osteogenic zones in the dorsal sector are continuous (large-headed arrow), and in the ventral sector have disappeared (small-headed arrow). The area within the square is enlarged in Fig. 10. Van Gieson method, $\times 10$. Fig. 10. Detail from Fig. 9. Centrum D's cranial end plate facing the space between Centra $C$ and D (iCD) is slightly thickened, while its caudal end plate facing the space between Centra D and E (iDE) shows extensive thickening. The border of declining concavity has a different location in the dorsal and ventral sectors (short arrows). Collagenous fibers in cartilage-like tissue between the end plates (long arrow), and in apparently increased amounts in the fibrous sheath (open curved arrow). $\times 47$ 


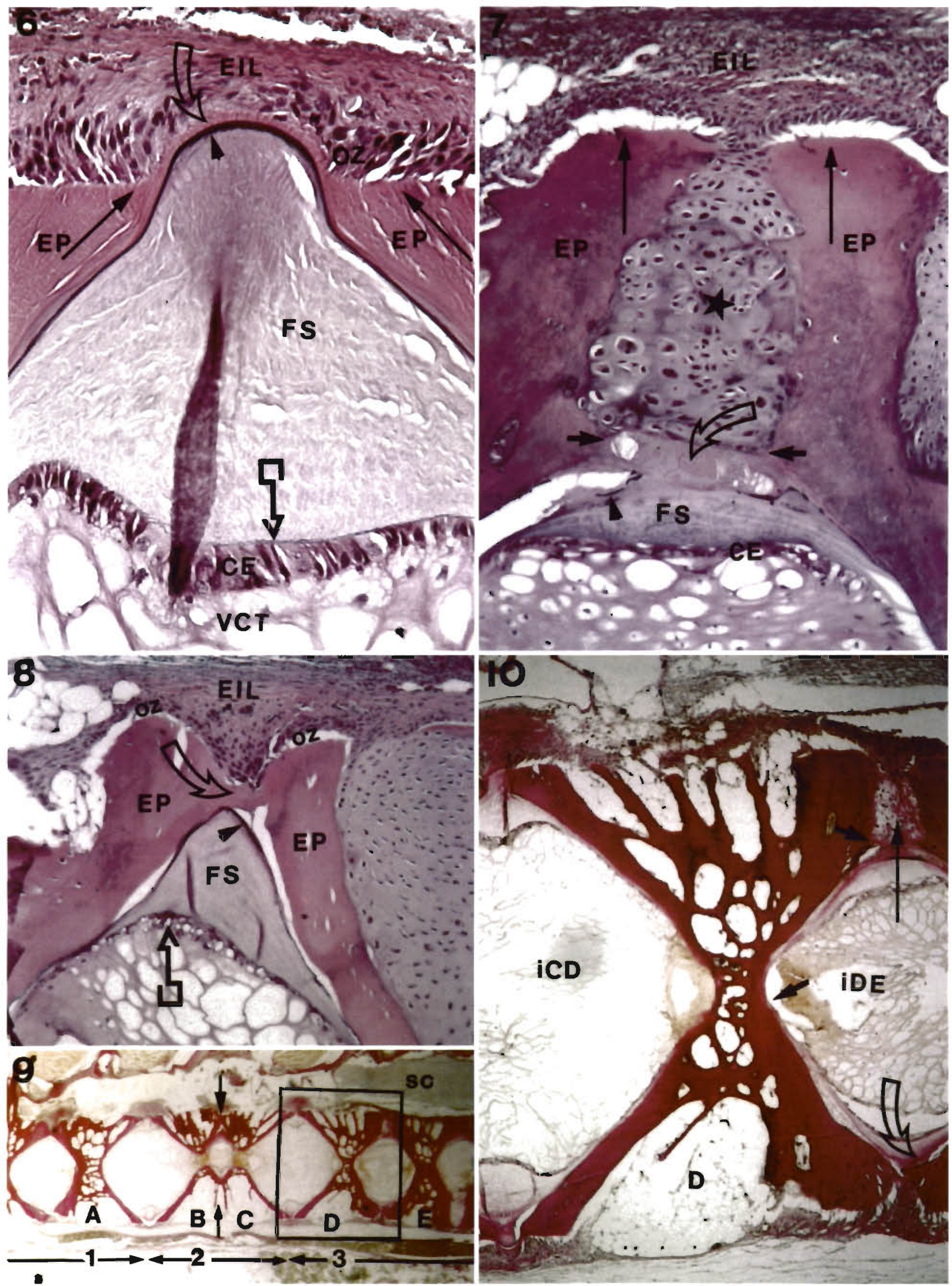


degree of concavity (Figs. 7 to 10). The transition between the different degrees of concavity will be referred to as the border of declining concavity.

In the transition between a section with changes and a section with apparently no changes, a centrum with changes only in the half facing the section with changes frequently occurred (Figs. 5 \& 9).

The extent of change in intercentral tissue was related to the extent of change in the end plates, i.e. to the position of the border in the axial-abaxial direction (Figs. 7, 8, 13 \& 14). In the least pronounced cases, changes were recorded only along a narrow rim along the peripheries of the end plates, in some cases in combination with an apparently increased number of chordal epithelial cells containing a cytoplasmic vacuole. In more advanced cases the fibrous sheath was irregular; a more or less fragmented external elastic membrane spanned the intercentral gap just axial to the border of declining concavity and the internal periosteal ligament disappeared. An irregular cartilage-like tissue proliferated in the intercentral space between the border and the more abaxial external intervertebral ligament. There was proliferation of connective tissue and blood vessels in and abaxial to the external intervertebral ligament. Basophilic particles or fibers occurred on fibers of all the connective tissue mentioned above.

The maximum degree of change was found in sections consisting of many short centra with reduced or no concavity in both end plates, and between which were large masses of cartilage-like tissue and, axially, remnants of destroyed chordal tissue were located (Figs. $9 \& 10$ ). Other cases showed the formation of an ankylosis between the peripheries of opposing end plates.

In connection with many of the biconid tubes with changes, there were basophilic sheaths in the fibrous sheath segment that represents the vestige of the chordacentrum (Figs. 11 \& 12).

There was slight to moderate infiltration with mononuclear and polymorphnucleated inflammatory cells in the meninges, especially in the ventral parts, and in other connective tissue along many of the sections with extensive changes. Mast cells, formerly called eosinophilic granular cells (Reite \& Evensen 1994), occurred in moderately increased number in the same locations (Fig. 15)

\section{Fish from seawater}

Affected fish displayed body malformation and vertebral changes like those in parr (Table 1), but more frequently the changes were located in 2 or more separate sections. Macroscopically there was extensive proliferation of connective tissue around and in altered columnal sections. A white tissue was seen in the intercentral space between a prominent border of declining concavity and a moderately thickened external intervertebral ligament.

Unlike parr, the radiodensity of slightly to moderately affected centra had not clearly increased (Figs. 16 to 18 ) when compared with centra without detectable changes. In the transition to a section with apparently normal vertebrae, there was a gradual change in the length and shape of the centra, with the more extensive changes in that half of a centrum facing the middle of the section with changes. Pairs of centra with the most extensive changes in opposing end plates occurred occasionally, as did ankyloses between the peripheries of end plates.

Examination of fleshed columns revealed opposing end plates with changes to be mirror images of each other, each with a continuous circular border of declining concavity at some distance from the columnal axis. The border on both opposing end plates was located more axially in the sector that displayed the most extensive changes. Several centra had their maximal degree of change localized in different sectors of their component end plates. In short centra there was less space between neural or haemal arches and zygapophyses.

Figs. 11 to 15. Salmo salar. Micrographs of sections. Formalin-fixed, decalcified, HE. Figs. 11 to 12. Median section from the level of the communicating canal (CoCa) between the 2 halves of the lacuna (L). Component end plates (EP), external elastic membrane (long arrows), fibrous sheath (open curved arrow) and chordal cells (ChCe). The vestige of the chordacentrum corresponds to the slightly more eosinophilic part of the fibrous sheath that extends between the short arrows. $\times 300$. Fig. 11 . No detectable changes Fig. 12. Changes in the component end plates. Irregular external elastic membrane, thick fibrous sheath with areas of increased basophilia ( 3 ), strongly basophilic sheaths (arrowhead) in the vestige. Masses of chordal tissue obliterate the canal. Figs. 13 to 14 Abaxial part of intercentral space and opposing end plates (EP) with mainly an abaxial direction of growth in the osteogenic zones (OZ). Fig. 13. The external intervertebral ligament (EIL) and the internal periosteal ligament (IPL, open curved arrow) are irregular, and the external elastic membrane (thin arrows) is fragmented. There are basophilic fibers (arrowheads) in IPL and in EIL, and small basophilic grains ( 3 ) in fibrous sheath (FS) $\times 300$. Fig. 14. Irregular dense sheath (open curved arrow) and internal periosteal ligament. Areas of increased basophilia (3) in the FS. Many chordal epithelial cells (CE) with a cytoplasmic vacuole. $\times 120$. Fig. 15. Mast cells (short arrow), polymorphnucleated inflammatory cells (open curved arrows) and cells resembling lymphocytes (arrowhead) between the meninges and external intervertebral ligament. $\times 470$ 


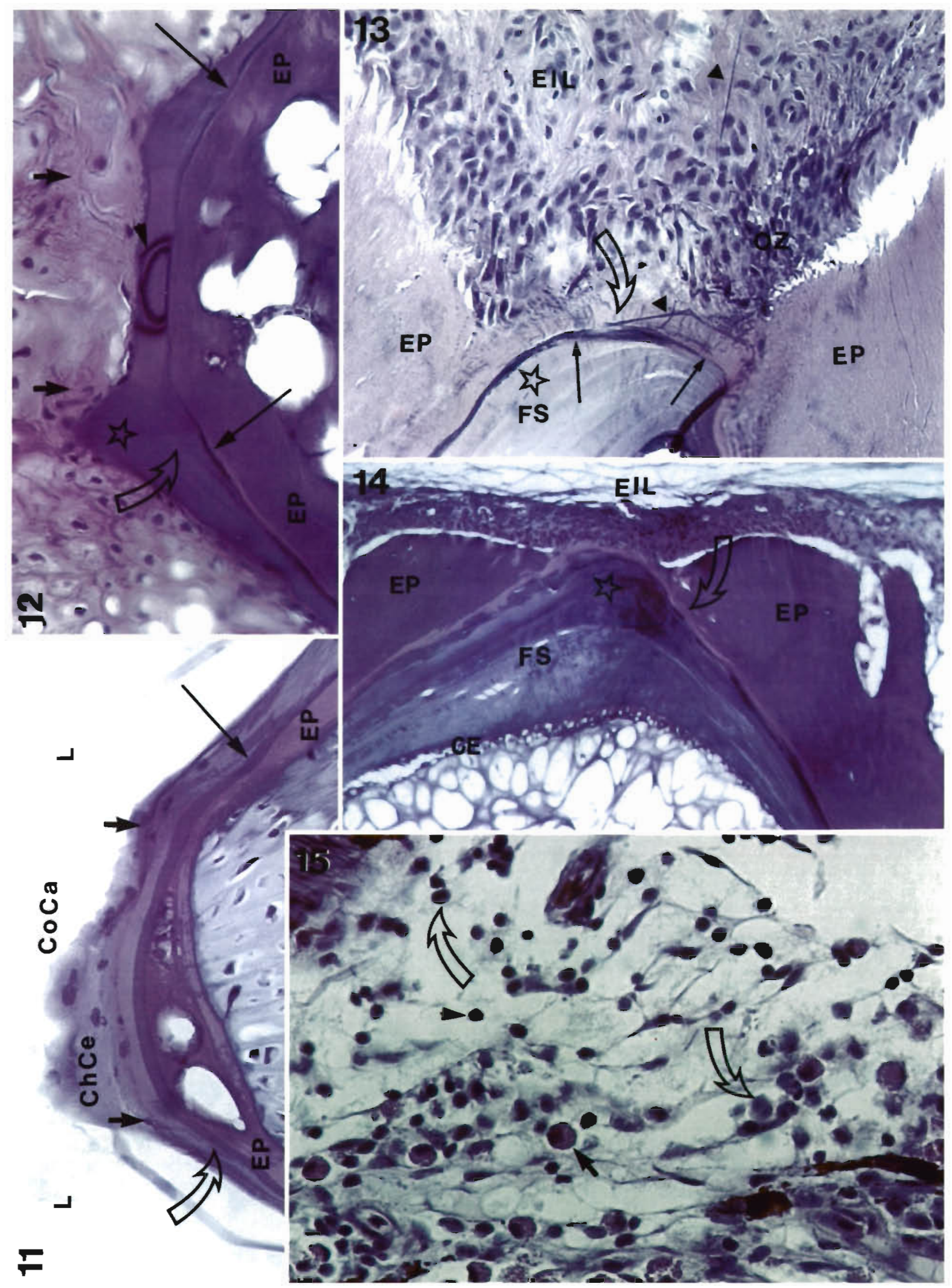


The localization of the border in the axial-abaxial direction varied considerably, both within and between fish (Figs. 19\& 20). End plates with peripheral thickening and reduced degree of concavity were the slightest histologic changes recorded. The macroscopic white tis- sue between the peripheries of end plates was similar to the tissue described in the same location in parr, as were changes in the internal periosteal ligament, membranes, fibrous sheath and vacuolated chordal tissue. Basophilic fibers or grains on collagenous fibers were prominent.
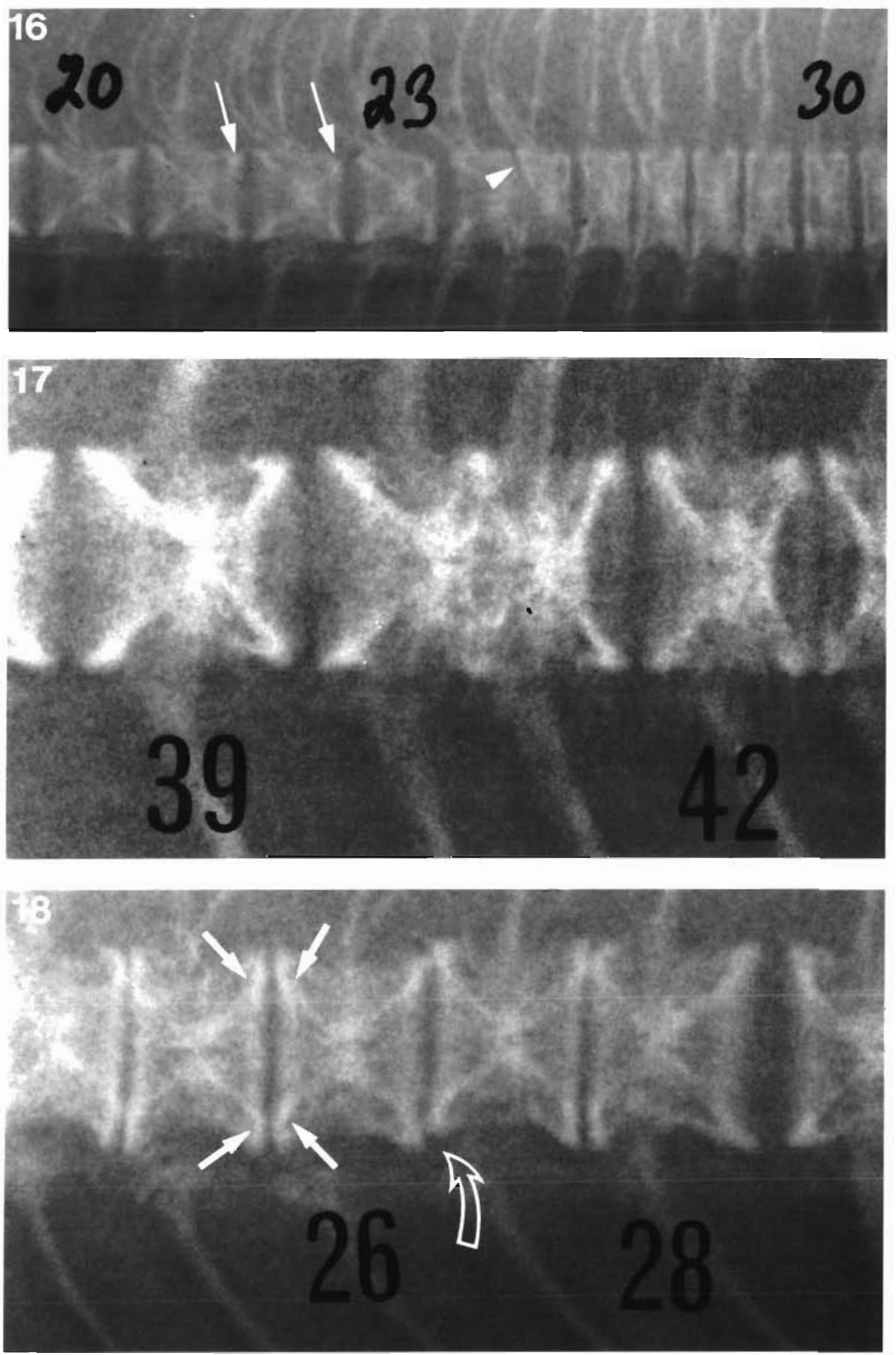

Fig. 16. Salmo salar. Radiograph of an apparently normal Centrum 20, where length approximately equals diameter, of a transition consisting of Centra 21 to 24 and of a section consisting of short centra. The border of declining concavity is visible in Centra 21 to 23 (arrows), and the caudal end plate of Centrum 24 is convex (arrowhead). $\times 1.7$

Fig. 17. Salmo salar. Radiograph of short centra, where Centrum 39 is shorter in its caudal half and ankylosis occurs between Centra 40 and 41. See also Fig. 19 of histologic section through Centra 41 and $42 . \times 5.2$

Fig. 18. Salmo salar. Radiograph from a column with slight changes in which centra are abnormally short. The border of declining concavity is marked in Centra 25 and 26 (short arrows), and there is additionally a partial dislocation between Centra 26 and 27 lopen curved arrow). $\times 3.6$ 
In columnal sections with changes, especially in the vertebral canal along the meninges and close to the thickened external intervertebral ligament, but also in connective tissue around the column and occasionally in supraspinal and infraspinal ligaments, moderate to extensive infiltration with inflammatory cells was seen (Figs. 21 to 24). A few arterioles were inflamed (Fig. 25), and there was extensive proliferation of capillaries in the adventitia of some arteries along sections (Fig. 26). A slight to moderate degree of interstitial fibrosis, few to some inflammatory cells, and necrotic myocytes in skeletal muscle were seen close to columnal sections with extensive changes.

\section{DISCUSSION}

Most of the changes recorded in this material are of the end-stage type, and the pathomorphologic picture in both parr and seawater-transferred fish is complex and shows great variation. We will discuss 6 types of similarity in changes in both age groups, which both represent growing fish.

Firstly, end plates with a thickened periphery and a reduced degree of concavity were the slightest changes that we with certainty recorded in both groups, and these are similar to those described as initial by Wunder $(1975 a, b)$. The pathologic process implied a more abaxial and less longitudinal direction of appositional growth, resulting in centra with increased diameter that did not attain the length that they should. This interpretation as a growth disturbance leading to malformation is supported by the view that under normal growth there is no need for remodelling of the biconid tube (Hübner 1961), and by our observations of high axial degree of concavity and of no osteoclasts in end plates with or without changes. Therefore, to describe the state of abnormally short centra, the term platyspondyly is preferable over terms like shortening, compression, deformation or remodelling. When the changes in several adjacent biconid tubes occur on average around the entire periphery, the result is a column that is sectionally short, but straight. A disturbance of appositional growth may also occur on one and the same side of several adjacent centra, resulting in scoliosis (Hübner 1961).

Secondly, the variation in degree of change in end plates, spanning from a reduced degree of concavity all over in the axial-abaxial direction, as observed in parr, to changes only in the abaxial part, as observed in both groups, suggests that the pathologic process starts at different ages. This view is supported by the fact that the frequency of macroscopically visible changes in farmed Atlantic salmon may increase significantly during the second year in seawater life
(McKay \& Gjerde 1986, Bæverfjord et al. 1996, Høie \& Breck 1996). It is also in accordance with some cases in which changes were confined to large fish (Wunder 1971). The basophilic sheaths observed in the vestige of the chordacentrum in parr may, if they are primary to the other changes, indicate that the pathologic process in this age group started before the autocentrum anlage existed, which would imply a disturbance of development, i.e. dysplasia.

Thirdly, our observations that opposing end plates are mirror images of each other and that changes tend to be located in opposing end plates only or to be maximal in opposing end plates are very similar to those changes published by Vávra (1906) and Wunder (1971, 1975a). This indicates that changes start to develop in the intervertebral tissue or the unit comprising intervertebral tissue and opposing end plates. The occurrence of similar short centra in cartilagenous fish (Hoenig \& Walsh 1983) could indicate that the changes do not primarily occur in bony tissue. Cells in the chordal epithelium, in the external intervertebral ligament, in the osteogenic zones of the opposing end plates and along the internal periosteal ligament are of paramount importance for growth of chordal and central tissue. Henschke et al. (1982) and Schäferna (1923) claimed that changes originate in chordal tissue. The results of this examination, with apparently initial changes in the peripheries of opposing end plates, rather indicate that changes originate in the more abaxial of the above-mentioned structures.

The presence of inflammatory cells is the fourth change to be described, and this is apparently the first description of these cells, as they are not mentioned in previous histologic examinations of short columns (Vávra 1906, Schäferna 1923, Henschke et al. 1982, Hansen \& Yalew 1988, Lom et al. 1991) or columns with similar changes (Couch et al. 1979). RubensDuval \& Desse (1972), who also found protrusion of chordal tissue into the vertebral canal, state that no inflammatory lesions were found.

Fifthly, the mainly caudal localization of changes in the body, as also described by Hansen \& Yalew (1988) and Bæverfjord et al. (1996), may possibly be related to the mode of swimming, with maximal side-to-side amplitude of the undulations in the caudal part of the body (Lindsey 1978), where the column is more flexible (Hübner 1961).

Lastly, similar end-stage changes develop in both groups. A continued growth of muscle myomeres in combination with reduced or no growth of columnal sections in the cranio-caudal direction, result in a short and thick body region (Wunder 1975b). Short and malformed centra, destruction of intercentral tissue, proliferation of cartilage-like tissue or ankylosis, are the results of prolonged pathologic processes (Wunder 


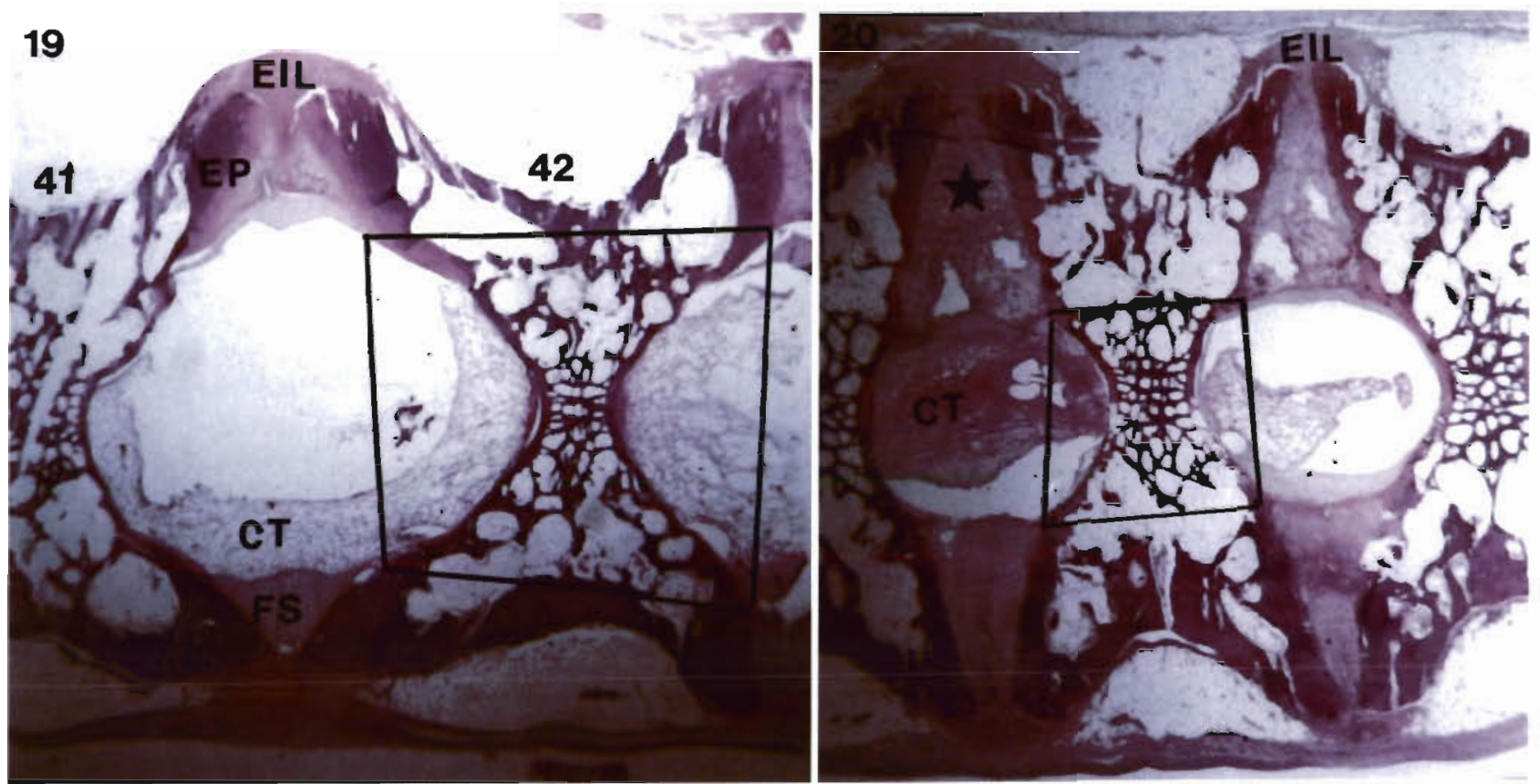

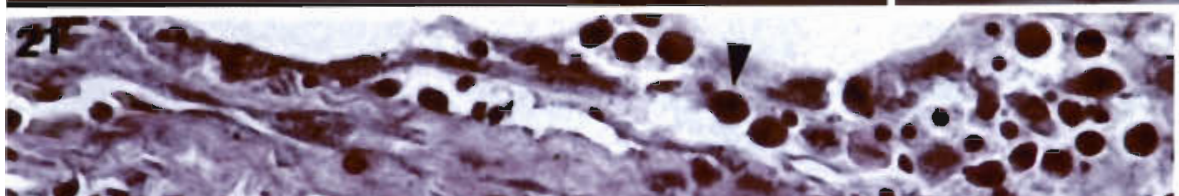
$00-1>20005$ ?

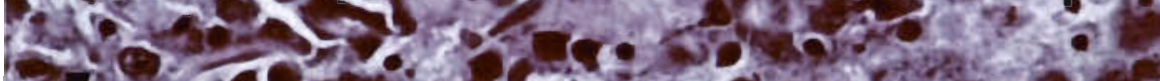
$700000.08+1 \times 00$

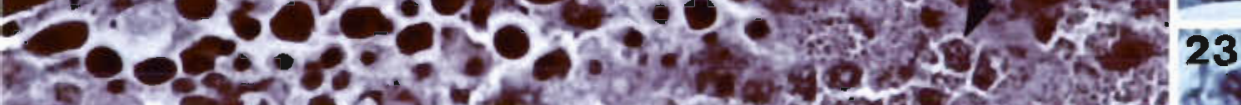

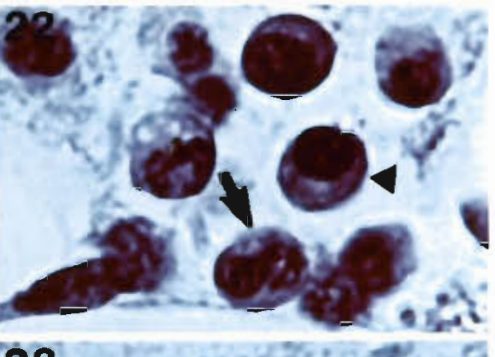

5.5.

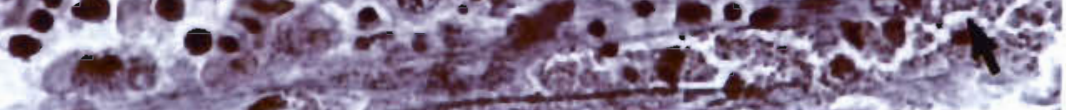
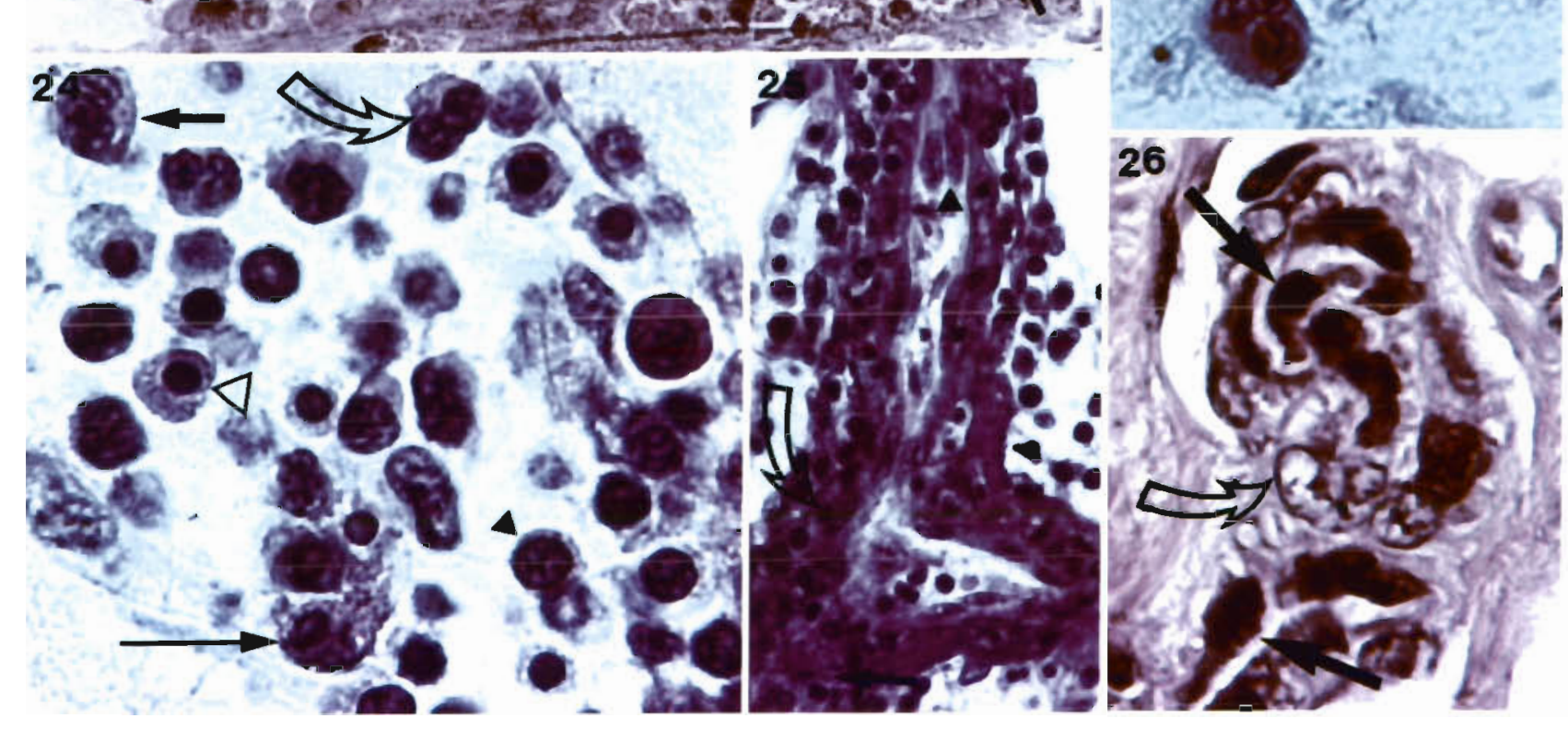
Figs. 19 to 26. Salmo salar. Micrographs of sections. Figs. 19 to 20. External intervertebral ligament (EIL), end plate (EP), fibrous sheath (FS), chordal tissue (CT). The frames have their corners at the border of declining concavity, and are not rectangles because changes may become visible at different times in the 2 halves and their sectors, and the section may not be parallel with the median plane. As the sections are paramedian, the frames do not indicate the full size of the biconid tube at the time when histologic changes emerged. Formalin-fixed, decalcified, HE. Fig. 19. Section from centra shown in Fig. 17. Slight changes in ventral and moderate changes in dorsal sector of opposing end plates of Centra 41 and 42 , with thickened peripheral parts of the end plates growing in a more abaxial direction. $\times 9$. Fig. 20. Extensive changes, with cartilage-like proliferations ( $\star$ ) and destruction of internal periosteal ligament, fibrous sheath and chordal tissue. $\times 10$. Figs. 21 to 25 . Inflammatory cells along outside of the meninges in columnal sections with changes. Fig. 21. Extensive infiltration with macrophages (arrowheads) and other inflammatory cells, among them mast cells (arrows) in the meninges (lower right). Formalin-fixed, decalcified, HE, $\times 470$. Fig. 22. Polymorphnucleated cell (arrow) and cell resembling plasma cell (arrowhead). Formalin-fixed, HE, $\times 1200$. Fig. 23. Polymorphnucleated cell (arrow). Formalin-fixed, HE, $\times 1200$. Fig. 24. Cell with cuneiform nucleus (short thick arrow), polymorphnucleated cell (open curved arrow), cell resembling a lymphocyte (filled arrowhead) and mast cell (long thin arrow). Cells with small, rounded and dense nucleus and abundant weakly-basophilic cytoplasm (open arrowhead) are of unknown type. Fixed in Bouin's fluid, $\mathrm{HE}_{2} \times 1200$. Fig. 25. An arteriole between the meninges and the supraspinal ligament. Hypertrophied endothelial cells (arrowhead), apparently degenerative changes in the tunica media (filled arrow), and many mononuclear inflammatory cells in the wall (open curved arrow) and around the vessel. Fixed in Bouin's fluid, HE, $\times 470$. Fig. 26. Capillaries in the tunica adventitia of an artery in a section with changes. Endothelial cells (filled arrows) with a dense nucleus and an amphiphilic cytoplasm, are surrounded by big cells containing a blastic nucleus (open curved arrow). Formalin-fixed, HE, $\times 1200$

1975b). The spinal cord and the nerves may be damaged due to insufficient space, inflammation and fibroplasia. Short biconid tubes with thick end plates result in an increased content of bony tissue per unit length of column in affected sections, which may explain the increased radiodensity and resistance to cutting in parr.

As regards etiology, the presence of many inflammatory cells around several short centra could indicate an infectious state where the inflammation may influence the appositional growth direction and growth of the ligaments. Very similar macroscopic and radiographic columnal changes have been reported in wild perch Perca fluviatilis with Myxobolus sandrae infestation (Lom et al. 1991), although inflammatory cells were not mentioned in the histologic description.

In sheepshead minnow Cyprinodon variegatus, apparently similar radiographic and histologic changes where some end plates with changes displayed a border of declining concavity occurred after experimental long-term exposure to trifluralin (Couch et al. 1979), a mitotic disrupter herbicide in plants (Hoffman \& Vaughn 1994) and animals (Sentein 1977). Apparently similar macroscopic and radiographic changes have been described in salmonids after accidental and experimental chronic exposure to trifluralin in a commercial formulation of unknown purity (Wells \& Cowan 1982). Due to their activity, the cells in the area comprising osteogenic zones, external intervertebral and internal periosteal ligaments could be vulnerable to a mitotic disrupter, and this may explain the pathologic changes observed. Therefore, both an inflammation and trifluralin may act by disturbing the same cells in their activity.
Studies have indicated that in farmed Atlantic salmon in Norway, the cause may be partly genetic (McKay \& Gjerde 1986, Vågsholm \& Djupvik 1998), and similar changes in fish have been described as an hereditary condition (Schäferna 1923, Wunder 1947. 1949).

In summary, initial pathologic changes seem to occur in the area comprising osteogenic zones, external intervertebral and internal periosteal ligaments, and manifest as a growth disturbance that results in platyspondyly and can be recognized at different ages. The degree of inflammation is highly variable. Short columns have been described in connection with trifluralin poisoning and infestation with Myxobolus sandrae, and as an hereditary condition, but in most cases the etiology is unknown. Inflammatory cells should be looked for in fish with a short column, and further examinations in farmed Atlantic salmon should focus on the issue of why these cells are present.

Acknowledgements. This project was funded by the Norwegian Research Council. We are extremely grateful to the following staff-members of the Norwegian School of Veterinary Science: Bernadette Helmer for assistance with radiographs, Inger Catrinius for photographic assistance, Ingjerd Andersen for mounting the photographs, David Griffiths for valuable discussion and language correction, and the library for valuable assistance. From the Veterinary Institute, we also thank Arild Kristensen and colleagues for preparing histologic sections and Ida Skaar for preparation of drawings.

\section{LITERATURE CITED}

Bæverfjord G, Åsgård T, Gjerde B, Holmefjord I (1996) Ryggdeformitet hos laks skuldast ikkje innavl eller genfeil (Spinal deformities in Atlantic salmon are neither caused by inbreeding nor genetic defects\}. Norsk Fiskeoppdrett $10: 34-35$ 
Chabanaud P (1939) Quelques monstruosités chez des poissons hétérosomes. Sympiézospondylie, atélurie et sphincturie. Arch Mus Hist Nat (Lyon) 15:1-23

Couch JA, Winstead JT, Hansen DJ, Goodman LR (1979) Vertebral dysplasia in young fish exposed to the herbicide trifluralin. J Fish Dis 2:35-42

Culling CFA, Allison RT, Barr WT (1985) Cellular pathology Technique, 4th edn. Butterworths, London

Desse G (1971) Lésions rachidiennes des poissons. Rev Pathol Comp Méd Exp 8:249-255

Ebner V (1896) Über die Wirbel der Knochenfische und die Chorda dorsalis der Fische und Amphibien. Oesterr Akad Wiss Wien Math-Naturw Kl Sitzungsber 105:123-165

François Y (1966) Structure et développement de la vertèbre de Salmo et des téléostéens. Arch Zool Exp Gén 107: $283-326$

Gemmill JF (1912) The teratology of fishes. James Maclehouse and Sons, Glasgow

Gill CD, Fisk DM (1966) Vertebral abnormalities in sockeye pink, and chum salmon. Trans Am Fish Soc 95:177-182

Hansen HJ, Yalew ZT (1988) Morphologic features of perosomus ('short spine') in farmed salmon (Salmo salar). A preliminary report. Vet Radiol 29:52-53

Henschke F, Pesch HJ, Wunder W (1982) Cadmum-induzierte Wirbelsäulenankylose beim Blaufelchen. Pathol Res Pract $173: 359-368$

Hoenig JM, Walsh AH (1983) Skeletal lesions and deformities in large sharks. J Wildl Dis 19:27-33

Hoffman JC, Vaughn KC (1994) Mitotic disrupter herbicides act by a single mechanism but vary in efficacy. Protoplasma 179:16-25

Hoie S, Breck O (1996) Forekomst av 'korthale'-en rygg radsdeformitet hos laks ('Short tail'-a spinal deformity in Atlantic salmon). Norsk Fiskeoppdrett 8:24-25

Howes GB (1894) On synostosis and curvature of the spine in fishes, with special reference to the sole. Proc Zool Soc Lond 95-101

Hübner $H$ (1961) Die Wirbelsäule des Karpfens (Cyprinus carpio L.). Ein Beitrag zum Verständnis der Feinstruktur des Knochens bei dieser Fischart. Z Fisch Hilfwiss 10 429-505

Komada N (1983) Occurrence and formation of vertebral anomaljes in the cyprinid fish, Zacco platypus. Jpn J Ichthyol 30:150-157

Lindsey CC (1978) Form, function, and locomotion habits in fish. In: Hoar WS, Randall DJ (eds) Fish physiology. Academic Press, New York, p 1-100

Lom J, Pike AW, Dykova I (1991) Myxobolus sandrae Reuss 1906, the agent of vertebral column deformities of perch

Editorial responsibility: Otto Kinne (Managing Editor), Oldendorf/Luhe, Germany
Perca fluviatilis in northeast Scotland. Dis Aquat Org 12 $49-53$

McKay LR, Gjerde B (1986) Genetic variation for a spinal deformity in Atlantic salmon, Salmo salar. Aquaculture 52: $263-272$

Reite OB, Evensen $\varnothing$ (1994) Mast cells in the swimbladder of Atlantic salmon Salmo salar: histochemistry and responses to compound $48 / 80$ and formalin-inactivated Aeromonas salmonicida. Dis Aquat Org 20:95-100

Remane A (1936) Skelettsystem. I. Wirbelsäule und ihre Abkömmlinge. In: Bolk L, Göppert E, Kallius E, Lubosch W (eds) Handbuch der vergleichenden Anatomie der Wirbeltiere, Vol 4. Urban \& Schwarzenberg, Berlin, p 1-206

Rubens-Duval A, Desse G (1972) Aperçus sur la pathologie rachidienne des poissons. Rev Rhum 39:101-105

Schäferna K (1923) Bemerkungen zu der Wirbelsäuleverkürzung der Fische und zu der Erblichkeitsfrage dieser Erscheinung. Verh Int Ver Theor Angew Limnol 1:266-269

Sentein P (1977) Un inhibiteur de l'appareil achromatique qui altère les chromosones, la trifluraline. Arch Anat Microsc Morphol Exp 66:263-278

Tretjakoff D, Chinkus F (1927) Das Knochengewebe der Fische. Z Anat Entwicklungsgesch 83:363-396

Vágsholm I, Djupvik HO (1998) Risk factors for spinal deformities in Atlantic salmon Salmo salar, L. J Fish Dis $21: 47-53$

Vávra V (1906) Über einen Fall von Wirbelsäulenverkürzung bei einer Regenbogenforelle (Salmo indaeus W. Gibb.). Bull Int Acad Sci Bohême 11:1-5

Wells DE, Cowan AA (1982) Vertebral dysplasia in salmonids caused by the herbicide trifluralin. Environ Pollut A 29 : 249-260

Wunder W (1947) Wirbelsäulenverkürzung beim Karpfen eine offenbar erbliche Erscheinung. $Z$ Naturforsch Teil B. Chem Biochem Biophys Verw Geb 2:239-243

Wunder W (1949) Wirbelsäulenverkürzung als rassebildendes Merkmal beim Aischgrunder Karpfen. Wilhelm Roux' Entwicklungsmech Org 144:1-24

Wunder W (1971) Missbildungen beim Kabeljau (Gadus morhua) verursacht durch Wirbelsäulenverkürzung. Helgol Wiss Meeresunters 22:201-212

Wunder W (1975a) Röntgenanalysen verkürzter Fischwirbelsäulen. (A) Kabeljau (Gadus morhua L.) und (B) Maifisch (Alosa alosa L.). Arch Hydrobiol 75:366-401

Wunder W (1975b) Verkrüppelte Felchen aus den Bodensee. Blaufelchen (Coregonus wartmanni Bloch) und Gangfisch (Coregonus macrophthalmus L.). Ursache: Wirbelsäulenverkürzung (Toxische Osteosklerose). Zool Anz 194: $279-292$

Submitted: December 14, 1998; Accepted: September 23, 1999 Proofs received from author(s): December 12, 1999 